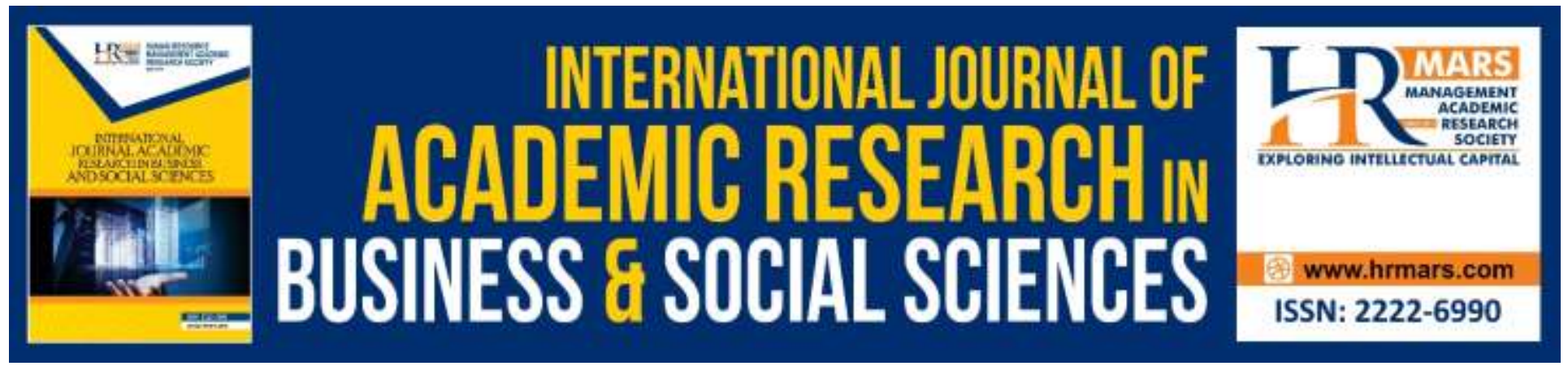

\title{
The Iranian Revolution of 1979: Confronting Theories of Revolution and Charisma
}

\section{Hamoon Khelghat-Doost}

To Link this Article: http://dx.doi.org/10.6007/IJARBSS/v10-i4/7153

DOI:10.6007/IJARBSS/v10-i4/7153

Received: 26 February 2020, Revised: 28 March 2020, Accepted: 10 April 2020

Published Online: 29 April 2020

In-Text Citation: (Khelghat-Doost, 2020)

To Cite this Article: Khelghat-Doost, H. (2020). The Iranian Revolution of 1979: Confronting Theories of Revolution and Charisma. International Journal of Academic Research in Business and Social Sciences, 10(4), 527-538.

Copyright: (C) 2020 The Author(s)

Published by Human Resource Management Academic Research Society (www.hrmars.com)

This article is published under the Creative Commons Attribution (CC BY 4.0) license. Anyone may reproduce, distribute, translate and create derivative works of this article (for both commercial and non-commercial purposes), subject to full attribution to the original publication and authors. The full terms of this license may be seen at: http://creativecommons.org/licences/by/4.0/legalcode

$$
\text { Vol. 10, No. 4, 2020, Pg. } 527 \text { - } 538
$$

Full Terms \& Conditions of access and use can be found at http://hrmars.com/index.php/pages/detail/publication-ethics 


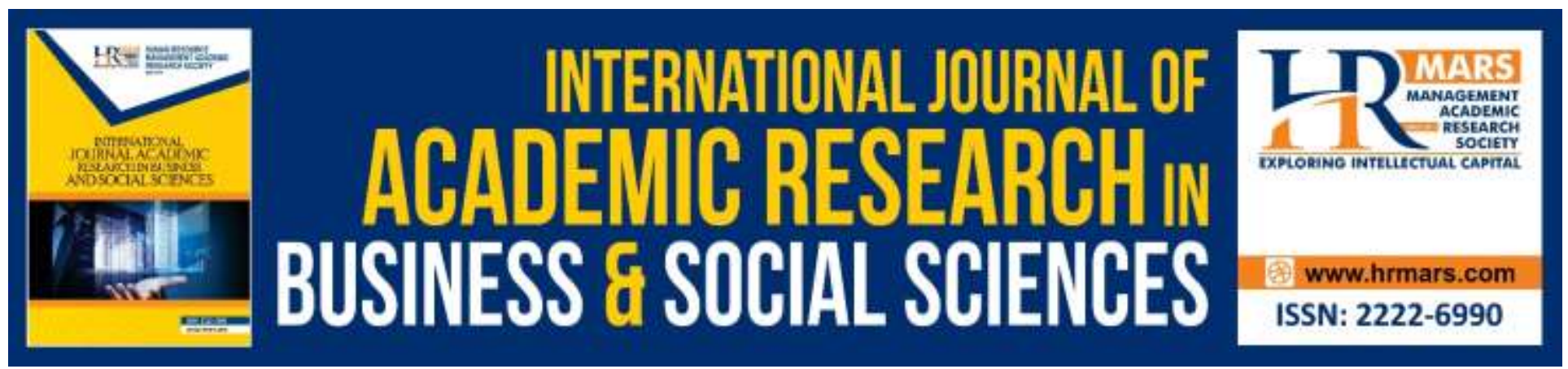

\title{
The Iranian Revolution of 1979: Confronting Theories of Revolution and Charisma
}

\author{
Hamoon Khelghat-Doost \\ Centre for Global Sustainability Studies Universiti Sains Malaysia \\ Email: hamoon@usm.my
}

\begin{abstract}
Contrary to the economic, political or cultural elements necessary for a revolution as described in conventional theories of revolution by scholars such as Skocpol and Marx, the Iranian Revolution occurred in 1979. It is argued that essential reasons for the occurrence of a revolution include defeat at war, peasant rebellion, gigantic national debt or disgruntled military. Absence of these reasons made the Iranian of 1979 a shock to the world. This paper therefore seeks to provide answer to the key question of why the Iranian revolution was a surprise to all existing theories of revolution? To do so, this paper critically examines Marx's and Skocpol's theories of revolution with regard to the Iranian Revolution of 1979 and discusses the shortcomings of these theories in explaining the Iranian Revolution. The paper will also argue why the Iranian revolution cannot fit the above-mentioned theories. This paper will also examine Max Weber's notion of charisma in relation to Ayatollah Khomeini - the leader of the Iranian Revolution.
\end{abstract}

\section{Introduction}

The Iranian Revolution of 1979 (a.k.a. Islamic Revolution) occurred at a time when none of the economic, political or cultural elements necessary for a revolution (as described in conventional theories of revolution by scholars such as Skocpol and Marx) were present in Iran. For this reason, the Iranian was a surprised not only for politicians but also for scholars in the field of political science. In the early 1950s, the Shah of Iran initiated an ambitious process of transforming the economy of the country from a landlord-peasant system to a capitalist one (Najmabadi, 1987). To achieve the objectives of this ambitious plan, the Shah started a nationwide aggressive industrialization scheme which was composed of a comprehensive import-substitution policy accompanied by a land reform program that began its operation in 1962 (Yaghmaian, 1988). At the time of starting the land reform, nearly $54 \%$ of the Iran's total labor force was engaged in agriculture and the large landowners were owning and running $70 \%$ of all cultivated lands in Iran (Clawson, 1977). The land reform completed in 1971.

The Shah sustained Iran's economic development initiatives by commencing a number of social and economic reforms which, together with progressively rising revenues from petroleum exports, allowed the economy to experience one of its most impressive periods of growth and low inflation (Pesaran, 1985). Over the period 1963-77, the economy's collective output, measured by its Gross 
National Products at constant prices, rose by an average annual rate of $10.5 \%$, while price increases were confined to average annual rates of between 2.6\% and 3.0\% (Pesaran, 2011).

From an economic point of view, the world in 1979 was divided into the two blocs of capitalism and socialism, without which no major economic movement at the time could have independently existed. Politically, the two poles of liberalism and Marxism dominated the world, with most political movements having adopted some variation of either dominant political school of thought in the realization of their goals (Leeds and Mattes, 2007). This was also a time in world history where culturally speaking, religion and its related ideologies were largely marginalized. For more than a century in the Western world, a large number of theories denied, or highly sidelined, the role of religion in a society's socio-political affairs; concurrently, Marxism's materialistic approach toward social interactions completely excluded religion. Against this backdrop, the Iranian Revolution as a form of social revolution rooted in Shi'a religious ideologies was a surprise to all existing theories of revolution. As Ermakoff (2004) explains, the conventional theories of revolutions "wrap their claims as if they could have predictive value." Following this notion, no major theories were able to predict or explain the Iranian Revolution when it occurred in 1979.

Studying these theories and their relations to the Iranian Revolution is particularly interesting when one considers that the Revolution not only ended Iran's 2500-year-old legacy of monarchy, but also introduced religious ideology as a key factor that is capable of mobilizing a social revolution. Religion has never been used in any revolution as the motive to rebel against the existing political orders. As Sepehri (2000) argues, "the Iranian Revolution launched Islam as a new liberating force in the eyes of many in the Middle East." In light of such development, religion (Islam) and its related values underwent a global paradigm shift - from the periphery, to the center of political arguments. This in turn created a novel avenue through which conventional theories of revolutions and social change may be tested.

As relatively rare occurrences, revolutions (when they do happen) provide researchers with the opportunity to explore and test existing theories and literature pertaining to revolutions. Prior to the Iranian Revolution, most theories explaining revolutions based their arguments on structuralism; with similarities between the major French, Russian and Chinese revolutions utilized in the construction of a general theory that claimed to be able to explain future revolutions. Consequently, the Iranian Revolution raised reasonable doubts to this claim and challenged existing theories of revolution.

This paper therefore seeks to provide answer to the key question of:

- Why the Iranian revolution was a surprise to all existing theories of revolution?

To do so, this paper:

1. Critically examines Marx's and Skocpol's theories of revolution with regard to the Iranian Revolution of 1979 and discusses the shortcomings of these theories in explaining the Iranian Revolution, and

2. Argue why the Iranian revolution cannot fit the above-mentioned theories. In its last section, this paper will also examine Max Weber's notion of charisma in relation to Ayatollah Khomeini - the leader of the Iranian Revolution.

\section{Skocpol's Theory of Revolution and the Iranian Revolution of 1979}

Theda Skocpol is perhaps "the most ambitious and exciting of new generation of historicalcomparative sociologists who have focused their attention squarely on the big issue of social change" 
INTERNATIONAL JOURNAL OF ACADEMIC RESEARCH IN BUSINESS AND SOCIAL SCIENCES Vol. 10, No. 4, April, 2020, E-ISSN: 2222-6990 @ 2020 HRMARS

(Himmelstein and Kimmel, 1981). In this section, the paper firstly reviews the structure of her social revolution theory and later on argues why her theory failed to explain the Iranian revolution of 1979. In her renowned book State and Social Revolutions, she takes a comparative structural approach towards the notion of social revolutions. She defines social revolutions as "very rapid and fundamental transformations of social conditions and class structures; they are achieved through the uprising of the lower class" (Skocpol, 1979). Skocpol however has selected the three examples of French, Russian and Chinese revolutions which she considers successful social revolutions. She categorizes these three cases positive as all three revolutions have occurred within the capitalist industrialization time bloc and share several similarities among them - in particular, they were "wealthy and politically ambitious agrarian states, none of which was colonially subjugated" (Skocpol, 1979). In her theory of revolution, agrarian states were particularly of interest as she argues these states are more vulnerable to peasant rebellions (Skocpol, 1994). All her cases of revolution in her book were also occurred in agrarian bureaucracies.

In her approach, she puts these three cases in contrast with non-revolutionary cases of England, Prussia, Japan and Germany. She concludes that social revolutions are rare - particularly after World War II, as states became strong enough to disallow any form of social revolution due to their possession of stronger army and more stable and solid economy. The rarity of social revolutions has in turn made the finding of universal examples of such revolutions equally difficult.

Skocpol explains social revolution in three stages of "the collapse of the old regime state, mass mobilization of the peasantry into class-based uprising and the reconsolidation of state power by a new elite" (Himmelstein and Kimmel, 1981). She rejects the idea of the state's political legitimacy in contrast with McDaniel (1991) who considers it as a key element in preventing social revolutions. In her book, Skocpol clearly discards the notion that "social order rests on the consensus of the majority" (Skocpol, 1979). In her opinion, many states around the world are governed without political legitimacy, and to support her claim, she cited South Africa under the apartheid regime as an example. She also argues that the states' power of repression is largely ignored in many social theories.

Another controversial argument made by Skocpol in terms of the social revolutions is her opposition to the purposefulness of both the causes and processes of social revolutions (Skocpol, 1979). She argues that no successful social revolution has ever been 'made' by a mass-mobilizing, avowedly revolutionary movement. This then takes us to one of her most famous quotes, "revolutions are not made, they come" (Skocpol, 1979). Skocpol emphasizes the incapacitation of the state - rather than its legitimacy, as the key element in the process of a revolution. This incapacitation would ultimately pave the way for the masses to shape the revolution against the state's oppressive forces.

In her theory of revolution, Skocpol also emphasizes the importance in revolutionary causation of military defeat in foreign war and of pressures from abroad (Ahmad, 1982). She argues that such pressure is necessary for political split among dominant classes and the state which subsequently will be resulted in occurrence of revolution (Farhi, 1998).

However, the Iranian Revolution which ironically happened to occur in the same year which Skocpol's State and Social Revolutions was published -1979; fundamentally challenged her theory of revolution. In contrast to one of her essential preconditions for a social revolution, Iranian society prior to the Revolution was not agrarian. Overall, the country's rural population as a percentage of the total has declined steadily; falling to 61\% in 1966 and to 53\% percent in 1976 (Azkia and Hooglund, 2011). The agricultural sector had long lost its importance in the country's economic structure at the time of revolution in 1970s. 
INTERNATIONAL JOURNAL OF ACADEMIC RESEARCH IN BUSINESS AND SOCIAL SCIENCES Vol. 10, No. 4, April, 2020, E-ISSN: 2222-6990 @ 2020 HRMARS

By 1979, petroleum revenue was the main source of income for the Shah's regime in Iran. In total, the Iranian foreign exchange revenues were remarkably depending on the petroleum industry and international oil markets. The dependency on petroleum export income was the highest during the Shah period of rule; 92\% (Farzanegan, 2013). Dependency on petroleum export and its revenue has consequently transformed Iran into a rentier state. The rentier state theory indicates that since the state receives the external income (petroleum revenue in case of Iran) and distributes it in the society, it is relieved of having to impose taxation, which in turn means that the state does not have to offer concessions to society such as a democratic bargain or a development strategy (Gray, 2011). Ruling a rentier state disconnected the Shah from a particular social class or sector, which in turn meant that the regime's main connection with the Iranian people was only limited to petroleum income distribution.

In the 1970s, Iran's capitalist economy was fully tied to the global economy. Land reform in the mid1950s effectively ended the feudal structure of the Iranian economy which was one of the main obstacles toward modernization and in the country's pursuit of capitalism. At the same time, the condition of Iran's rural and agrarian society in 1979 fundamentally differed from Skocpol's perspective. The structure of Iran's rural areas and villages was largely different from their counterparts in Russia, China and France. The Iranian rural sector and its structure were never homogenous. In many villages, one family was in charge of the entire village; in others, a combination of influential families was administrating the village collectively. In other parts of Iran, a village was considered an operating unit on its own with the discretion to decide on how best to run itself. Elsewhere, individual families independently decided their own affairs (Lahsaeizadeh, 1993). The existence of a large number of nomads also made the Iranian rural sector substantially more complex and heterogeneous than cases studied by Skocpol in other western societies.

Through the land reform of 1960's, the Shah redistributed agricultural land among the sharecroppers who were farming it, thinking that this would buy their loyalty to his regime and assist in the modernization of the Iranian agricultural system (Pahlavi, 1980). The government also confiscated land from the landlords and distributed them among peasants, and this, coupled with other mechanisms, increased the state's influence and control in rural areas. Therefore, in contrast with Skocpol's core opinion on revolution, the Iranian revolution was the only modern social revolution in which the peasantry and rural guerrillas played a marginal role (Boroujerdi, 2005).

Simultaneously, the Iranian revolution did not meet another precondition set by Skocpol for a social revolution, namely international pressure. In 1979, the Iranian regime was not under significant international pressure. The Shah (while keeping close ties with the USSR) was a trusted key ally of the United States and the West. As Zanchetta (2009) argues, the American leaders constantly sought to secure a tight and positive relationship with the Shah. Nor was Iran involved in a war, or experiencing military defeat. There were no military exercises or entanglements occurring at the time that might have weakened the Iranian army from repressing a revolution. Indeed, the middle and high ranked officers of the Iranian army enjoyed a vast range of incentives offered to them by the Shah's regime. At the time, Iran's army was the strongest army in the region after Israel in terms of personnel training, organizational capabilities and modern weaponries (Karsh, 1987). As Wise (2011) describes, Iran had the most highly advanced, best trained military in the Persian Gulf area. It had the fourthlargest air force and fifth-largest military on the globe.

Based on what has been discussed in this section, the causal background and components of this historical event -Iranian revolution- did not fit Skocpol's expectations for the occurrence of a social revolution. Neither of parameters put forward by Skocpol to shape a revolution was existing in Shah's 
INTERNATIONAL JOURNAL OF ACADEMIC RESEARCH IN BUSINESS AND SOCIAL SCIENCES

Vol. 10, No. 4, April, 2020, E-ISSN: 2222-6990 @ 2020 HRMARS

Iran including an agrarian society and international pressure. For this reason, Skocpol's theory of revolution failed to explain the reasons for the Iranian revolution of 1979.

\section{Marx's Theory of Revolution and the Iranian Revolution of 1979}

In analyzing revolution, Marxism grants particular emphasis on the economic structure of a society. It is therefore the economy that gives identity to revolutions and defines their direction. However, in this section, this paper contends the claim that Iran's revolution of 1979 can be explained through the Marxist framework for revolutions. Following a brief explanation of Marxism's views on revolutions, this section argues the above claim by examining the following reasons: firstly, in contrast to the Marxist belief that a society's bourgeoisie and industrial proletariat are the driving forces of a revolution, it should be noted that Iran in 1979 had no significant bourgeois class. Secondly, the Iranian Revolution of 1979 was not an economically-fueled revolution, as individuals from different socio-economic sectors participated in all aspects of the Revolution. And lastly, the role of Shi'a ideology and the charismatic leadership of Ayatollah Khomeini must be collectively taken into account when discussing the case of the Iranian revolution.

Marxism is widely considered one of the most influential theories in the analyses of revolutions (Draper, 1989). It considers the entire trajectory of history as a form of revolutionary change, and economy as the basis of such change within a society. Marx believed that historically, the growth of agriculture and private property gave rise to the two key elements responsible for creating social conflicts; namely the division of labor and social classes (Cottrell, 2019). For this reason, Marx believes that the history of all hitherto existing society is the history of class struggles (Marx and Engels, 2005). Hence, as both conflict and struggle are inevitable, revolution is the resulting climax of structural change in a society. Marx explains that at a certain stage of development, the material productive forces of society come into conflict with the existing relations of production or with the property relations within the framework of which they have operated hitherto (Marx, 1904).

Marx believed that the existence of a feudalist structure and the means of production are important factors in the birth of a revolution. In Marx's opinion, the transition from feudalism to capitalism creates fundamental social changes within societies (Katz, 1993). Concurrently, the bourgeoisie is another critical element that sets the wheels of a revolution in motion. With changes in both the means and forces of production within a society, as well as the birth of the bourgeoisie, the feudal structure of a society finds itself increasingly in conflict (Bottomore et al., 1991). In time, this conflict will erupt and ultimately result in the overthrow of feudalism and its replacement with the bourgeoisie. This was emphasized by Marx in his statement; "the bourgeoisie is just as necessary a precondition for the socialist revolution as is the proletariat itself" (Marx, 1874).

However, the Iranian revolution of 1979 seems not to fit the structure theorized by Marxism. As the Iranian revolution was not an economically-fueled revolution, it is therefore difficult to explain this revolution by utilizing the Marxist lens (Keddie, 1983). An examination of the slogans and mottos of Iranian protesters during the Revolution reveals no trace of economically-charged demands. Instead, the slogans largely emphasized the need to overthrow the Shah's regime, and end Iran's political dependency on the West in addition of establishing an Islamic state. A large majority of the Revolution's slogans and demands were also religiously motivated and had little - if anything, to do with materialistic or economic demands.

The Marxist school of thought holds to the belief that poverty and class conflict are the primary causes instigating a revolution and Marxist thinkers have long utilized these two factors to explain most of the World's revolutions (Callinicos, 2012). Subsequently, in an attempt to counteract the 
INTERNATIONAL JOURNAL OF ACADEMIC RESEARCH IN BUSINESS AND SOCIAL SCIENCES Vol. 10, No. 4, April, 2020, E-ISSN: 2222-6990 @ 2020 HRMARS

possibility of a revolution, many countries have taken steps to eradicate poverty. This however fails to explain the Iranian revolution of 1979, as Iranians were economically much better off in the 70's prior to the Revolution. Iranians as a whole were much poorer during the 50's and 60's, and yet, the notion of a revolution did not appeal to them. Indeed, although the Iranian economy was facing difficulties in the last couple of years prior to the Revolution, the effects of these difficulties were obviously not enough to warrant a revolution. Interestingly, Iran's per capita oil income is about onefourth of what it was in the two years before the revolution of 1979 (Sanger, 1995). Instead, the need for a revolution only arose when protesters shaped their demands around revolutionary Shi'a discourse which will be discussed in the next section of this paper.

Furthermore, in the years prior to the Revolution, the Iranian economy enjoyed rapid growth with improvement being seen in the economic sphere of the community. Statistics indicate that by the 1970s "Iran had achieved significant industrialization and economic modernization based on an import-substitution model, largely aided by the growing worldwide demand for oil" (Global Edge, 2012). Through the revenue gained by the country's primary source of income - oil exports, the Shah had even initiated a nationwide welfare program in an attempt to increase the quality, as well as access, of Iranians to medical and social services. The formation of Sepah Danesh (the Education Army) to teach Iran's unschooled community to read and write was one of the most important social reforms of the Shah's public education policy. Approximately "638,000 children and 262,000 adults were able to read and write during the first five years" of this program, which lasted until 1979 (Hosseini, 2013).

Workers and peasants were also not the motivating factor behind the Iranian revolution. In fact, the strike by workers of the Iranian Oil Industries was the only instance where workers were involved in the Revolution of 1979. However, it should be paid attention that the Iranian Oil Industries workers were considered elites in comparison to workers in other sectors - both in terms of income and other materialist benefits. Their demands while striking were not at all economic, and were in fact, political. Their demands included "lifting martial law, prohibiting the army from entering the refinery, and release of all political prisoners" (Parsa, 1989).

Therefore, the Marxist idea on the active participation of workers and peasants in the process of a revolution is also not applicable to the Iranian revolution. Contrary to the Marxist notion of a revolution, those actively involved in the Iranian revolution were individuals from the middle class, Western educated intellectuals, and the religious elites. Furthermore, what makes the Iranian revolution unexplainable by Marxism is the dominating role of religion - particularly Shi'a Islam, coupled with the charismatic leadership of Ayatollah Khomeini. Concepts such as the impact of culture and religion on the internal workings of a revolution are heavily marginalized in Marxist theory, and yet, in defiance to this argument, the Iranian revolution of 1979 had religion as its core driving force. Subsequently, the role of religion, and leadership charisma, will be discussed in the following sections of this paper.

\section{Weber's Theory of Charisma and Ayatollah Khomeini's Leadership}

The Iranian revolution and its leadership could also be examined through Max Weber's social ideas particularly those on authority and legitimate dominations. In this section, the paper will review Weber's theory on charisma and argue the case of Ayatollah Khomeini the leader of the Iranian revolution from Weber's perspective. It also further explores the role of Shi'ism as a religious ideology in providing an apposite platform for Ayatollah Khomeini's charisma to be further enhanced. 
INTERNATIONAL JOURNAL OF ACADEMIC RESEARCH IN BUSINESS AND SOCIAL SCIENCES Vol. 10, No. 4, April, 2020, E-ISSN: 2222-6990 @ 2020 HRMARS

Weber defines domination (authority) as the "probability that certain specific commands (or all commands) will be obeyed by a given group of persons" (Weber, 1978). As an extension to this idea, Weber emphasizes further on the issue of legitimacy. He argues that the source of legitimacy would ultimately define the type of obedience and the administrative structure expected by an authority. In his opinion, legitimacy may either be materialistically, affectively or idealistically motivated (Spencer, 1970). Consequently, Weber classifies authority into the three categories of rational, traditional and charismatic.

According to Weber, rational authority is built on the belief in the legality of the laws, orders and positions of those in authority. With conventional authority on the other hand, the source of legitimation mostly rests in long-established traditions and beliefs in the sanctity of the administrative authority. Charismatic authority however, heavily emphasizes on the "exceptional sanctity, heroism or exemplary character of an individual person" as the leader (Conger and Kanungo, 1987). Both rationality and charisma are capable of creating revolutionary changes against tradition; however, the difference lays in the approach between these two concepts with regard to revolutionary changes. Rationality initially revolutionizes the social environment before changing the masses' worldview, while charisma primarily revolutionizes the personal beliefs and inner worldviews of the masses.

Although Weber neither views all charismatic authorities as revolutionary, nor assumes that all revolutions are charismatically based, he did believe that most contemporary revolutions were charismatically strong. As the most common means through which conventional legal regimes are overthrown, charismatic authority is of particularly high revolutionary potential (Saeidi, 2001). As stated earlier, this type of authority is based upon the extraordinary characteristics of its leader; whereby what matters most is the level of devotion the followers have for their leader's charisma. Weber also argues that what is the most important is how the individual is actually regarded by those subject to charismatic authority, by his followers and disciples (Weber, 1978). Charisma could therefore, be viewed as an inner bond or relationship between leaders and their followers with charismatic leadership materializing within charismatic movements. Charisma neither has rational nor traditional bases but is rooted mostly within passion and emotions and in the context of charismatic authority, followers accept a charismatic individual as their ultimate leader. A charismatic leader causes change within the political environment of a society by offering new dimensions through which to challenge the status quo, and by doing so, challenging the legitimacy of the existing authority, which in turn, transforms the charismatic leader into a revolutionary force.

Weber also believes in the philosophical importance of a charismatic character. He argues that modern society's extreme devotion to rationality has generated a sophisticated bureaucratic system that now endangers the freedom and thoughts of the individual. He posits that only a charismatic leader would be capable to lead society toward freedom, which could be taken to encapsulate the historical role of charismatic leaders in helping the masses rediscover their individual identity and freedom. Weber also believes that the charismatic leader should be capable of sustaining his charisma over time as if his leadership fails to benefit his followers, it is likely that his charismatic authority will disappear (Weber, 1978).

Applying Weber's theory of charisma in studying the charismatic role of Ayatollah Khomeini with regard to the Iranian revolution reveals interesting perspectives - particularly the role of traditional authority (Shi'ism) in providing the suitable environment for Ayatollah Khomeini's charismatic authority to enhance. Historically, charisma and charismatic leaders played fundamental roles within Iran's primary school of Islamic thought - Shi'ism. In contrast to Sunnis, Shi'as are bound by their 
teachings to choose a Grand Ayatollah as their lifetime Marja' (Source to Emulate or Religious Reference). Each Shi'a person should follow her/his Marja' and obey his fatwas concerning a wide range of issues spanning from religious rituals to social and political matters. The act of following a Marja' is referred to as imitation or taqlid, and the most import factor determining which Marja' an individual chooses boils down to the charismatic strength of the Marja' in question.

Shi'ism has greatly enhanced Khomeini's personal charismatic leadership abilities through a number of mechanisms - in particular, the Marja' concept paved the path to Khomeini's sanctity. Arguably, the emergence of a religiously sacred charismatic leader would not be possible within communities without a specific cultural reference to a relationship between the leader and his followers. The longestablished concepts of Marja' and taqlid (the conformity of one person to the teaching of a Marja') provided Khomeini with the opportunity through which to further enhance his charismatic religious and political leadership with the immense ability to mobilize his followers. For the same reason, in one of his famous speeches he described the Iranian revolution as Iranian masses have fought and only for God not worldly affairs (Foran, 1993).

Another unique phenomenon within Shi'ism that has greatly contributed to the augmentation of Khomeini's charismatic leadership is the epic of Ashura. This refers to an incident that occurred in the tenth of the month of Muharram in the Islamic calendar (October 10, $680 \mathrm{CE}$ ) where Hussein - the third Imam of the Shi'as, was killed in the Battle of Karbala against the ruling Sunni Caliph. Ashura is viewed by Shi'ism as the embodiment of concepts such as Shahadat (martyrdom), Welayat (Authority of the leader), the pursuit of justice, the battle against corruption and taslim (obedience to the divine ruler and righteous leader). The idea of rebellion and resistance against a religiously and politically illegitimate ruler is the political backbone of Ashura - an aspect heavily manipulated by Khomeini to further strengthen his charismatic leadership. In order to achieve this, Khomeini continuously equated Iran's situation at the time with the historic Shi'ite event of Ashura, and by so doing, drew an analogy of himself to the Imam Hussein in order to reinforce his religiously legitimate and charismatic image among his followers.

To bolster the strength of his charismatic leadership, he chose the title Imam for himself becoming known to all his followers and people around the world as Imam Khomeini. Again, this was an attempt by Khomeini to position himself with the 12 holy Imams of Shi'ism, which added to the sanctity and divinity of his image among the Iranian people, allowing him to further mobilize the Iranian masses. The basis of Khomeini's legitimation, and his claim that he and only he had the mission he believed called upon to perform was the mystical charisma he felt within himself (Ashraf, 1990). His personal charisma coupled with the opportunity that Shi'ism has provided for him, enabled Ayatollah Khomeini to legitimate the Islamic regime and its policies of militancy and repression among his followers (Parel and Keith, 2003).

\section{Conclusion}

Prior to the Iranian Revolution of 1979, the role of elements such as culture and the political narrations of religion were largely marginalized or ignored in discourses involving theories of revolution. Marxism for instance, believes in the materialist interpretation of historical development; in this worldview, revolution can only occur as a result of clashes between the development of material productive forces and the relations of production (Marx, 1904). However, as discussed in this paper, the religious component of the Iranian Revolution appears to be in contrast to Marxism's idea of a revolution. Elements such as the bourgeoisie, capitalism or class conflict - all of which were considered necessary elements of a revolution, did not exist in 1979 Iran. 
Concurrently, the Iranian Revolution also challenges Skocpol's theory of revolutions. None of the factors Skocpol deemed essential for a social revolution were present in 1979 Iran. The Iranian society was not an agrarian one in the 1970's and the country's petroleum revenue made the Shah independent of the income generated by both the agrarian and industrial sectors of the Iranian economy. Furthermore, the Shah's regime and armed forces were at the pinnacle of their military strength in 1979 with no foreign threat or military pressure from the global community. Nonetheless, despite the absence of elements vital to Skocpol's theory regarding revolutions, the Iranian Revolution of 1979 was a very real incident that fundamentally challenges her theory.

In the last part of this paper, the role of Ayatollah Khomeini as the Revolution's charismatic leader was discussed using Weber's theory of charisma; to this end, the Ayatollah Khomeini could be surmised as a successful implication of Weber's theory of charisma. Apart from the Ayatollah's personal charisma, the Shi'ism school of thought provided ideal conditions for the magnification of Khomeini's persona. As argued in this paper, Ayatollah Khomeini skillfully employed some of the most important elements of Shi'ism - particularly Marja', Taqlid, Welayat and Ashura, to further cement his charismatic rule as leader of the Iranian revolution.

\section{References}

Ahmad, E. (1982). Comments on Skocpol. Theory and Society, 11(3), 293-300.

Ashraf, A. (1990). "Theocracy and Charisma: New Men of Power in Iran," International Journal of Politics, Culture, and Society, Vol. 4, No. 1, pp. 113-152.

Azkia, M., and Hooglund, E., 2011. Rural Development in Contemporary Iran 1950-2010.

Boroujerdi, M. (2005) "Iran Briefing Paper," AP Comparative Government and Politics, Syracuse University, NY.

Bottomore, T., Harris, L., Kiernan, V. G., \& Miliband, R. (1991). The marxist thought. Oxford, England: Blackwell Publishers Ltd.

Callinicos, A. (2012). The revolutionary ideas of Karl Marx. Haymarket Books.

Clawson, P. (1977). "The Internationalization of Capital and Capital Accumulation in Iraq and Iran." Insurgent Sociologist, Spring: 66-73.

Conger, J. A., \& Kanungo, R. N. (1987). Toward a behavioral theory of charismatic leadership in organizational settings. Academy of management review, 12(4), 637-647.

Cottrell, A. (2019). Social Classes in Marxist Theory (Vol. 17). Routledge.

Draper, H. (1989). Karl Marx's Theory of Revolution (Vol. 4). New York University Press.

Ermakoff, I. (2007). "The Unthinkable Revolution in Iran," American Journal of Sociology, Vol. 113, No. 3, pp. 879-881.

Farhi, F. (1988). State disintegration and urban-based revolutionary crisis: A comparative analysis of Iran and Nicaragua. Comparative Political Studies, 21(2), 231-256.

Farzanegan, M. R. (2013). Oil and the Future of Iran: A Blessing or A Curse. Legatum Institute Future of Iran series, London.

Foran, J. (1993) "Fragile Resistance: Social Transformation in Iran from 1500 to the Revolution," Boulder, CO: Westview.

Global Edge. (2013). "Iran: Economy," available at: http://globaledge.msu.edu/countries/iran/economy

Goodwin, J. (1996), "Review of States and Social Revolutions, by Skocpol," Contemporary Sociology 25, 294. 
INTERNATIONAL JOURNAL OF ACADEMIC RESEARCH IN BUSINESS AND SOCIAL SCIENCES Vol. 10, No. 4, April, 2020, E-ISSN: 2222-6990 @ 2020 HRMARS

Gray, M. (2011). “A Theory of Late Rentierism in the Arab States of the Gulf," Center for International and Regional Studies, Georgetown University School of Foreign Service in Qatar. Occasional Paper No. 7.

Himmelstein, J. L., and Kimmel, M. S. (1981). "Review of States and Social Revolutions, by Theda Skocpol," The American Journal of Sociology, No. 86.

Hosseini, M. (2012). "The Iranian History Article : Sepah Danesh Corps Founded," Available at: http://www.fouman.com/Y/Get_Iranian_History_Today.php?artid=1241

Karsh, E. (1987). Military power and foreign policy goals: the Iran-Iraq war revisited. International Affairs, 64(1), 83-95.

Katz, C. J. (1993). Karl Marx on the transition from feudalism to capitalism. Theory and Society, 363389.

Keddie, N. R. (1983). Iranian Revolutions in Comparative Perspective. The American Historical Review, 88(3), 579-598.

Lahsaeizadeh, A. (1993). Contemporary rural Iran. Avebury.

Leeds, B. A., \& Mattes, M. (2007). Alliance politics during the Cold War: aberration, new world order, or continuation of history? Conflict Management and Peace Science, 24(3), 183-199.

Marx, K. (1874). On Social Relations in Russia (1874) MECW, Volume 24.

Marx, K. (1904). "A Contribution to the Critique of Political Economy," Charles H. Kerr.

Marx, K., and Engels, F. (2005). "The Communist Manifesto," in Phil Gasper, ed., The Communist Manifesto: A Road Map to History's Most Important Political Document (Chicago: Haymarket Books)

McDaniel, T. (1991). "Autocracy. Modernization. and Revolution in Russia and Iran." Princeton: Princeton University Press.

Najmabadi, A. (1987). Land reform and social change in Iran (pp. 50-168). Salt Lake City: University of Utah Press.

Pahlavi, M. R. (1980) "Answer to History," New York: Stein and Day.

Parel, A., and Keith, R. C. (Eds.) (2003). "Comparative political philosophy: Studies under the Upas Tree," Lexington Books.

Parsa, M. (1989). Social origins of the Iranian revolution. Rutgers University Press.

Pesaran, M. H. (1985). Economic development and revolutionary upheavals in Iran. In Iran (pp. 1550). Palgrave Macmillan, London.

Saeidi, A. A. (2001). Charismatic political authority and populist economics in post-revolutionary Iran. Third World Quarterly, 22(2), 219-236.

Sanger, D. E. (1995). Fear, Inflation and Graft Feed Disillusion Among Iranians. New York Times.

Sepehri, S. (2000). "The Iranian Revolution," International Socialist Review Issue 9.

Skocpol, T. (1979). "States and Social Revolutions: A Comparative Analysis of France, Russia and China," Cambridge University Press.

Skocpol, T. (1994). Social Revolutions in the Modern World. Cambridge University Press.

Spencer, M. E. (1970). Weber on legitimate norms and authority. The British Journal of Sociology, 21(2), 123-134.

Wise, K. (2011). "Islamic Revolution of 1979: The Downfall of American-Iranian Relations," Legacy: Vol. 11: Issue. 1, Article 2.

Yaghmaian, B. (1988). Internationalization of Capital and the Crisis of the Iranian Economy. Review of Radical Political Economics, 20(4), 40-56. 
INTERNATIONAL JOURNAL OF ACADEMIC RESEARCH IN BUSINESS AND SOCIAL SCIENCES

Vol. 10, No. 4, April, 2020, E-ISSN: 2222-6990 @ 2020 HRMARS

Zanchetta, B. (2009). "The United States and the 'Loss' of Iran," Working Papers in International History and Politics, No. 4. 